\title{
Improving teachers' competence on the use of internet of things for teachers in the city of Makassar
}

\author{
Yusminah Hala ${ }^{a, 1,}{ }^{*}$, Arifah Novia Arifin ${ }^{a, 2}$ \\ ${ }^{a}$ Biology Department, Faculty of Mathmetics and Natural Sciences, Universitas Negeri Makassar, Jl. Daeng Tata Raya, Parang Tambung, Makassar \\ 90224, South Sulawesi, Indonesia \\ 1yushala12@gmail.com*,2arifahnoviaarifin@unm.ac.id, \\ * Corresponding author
}

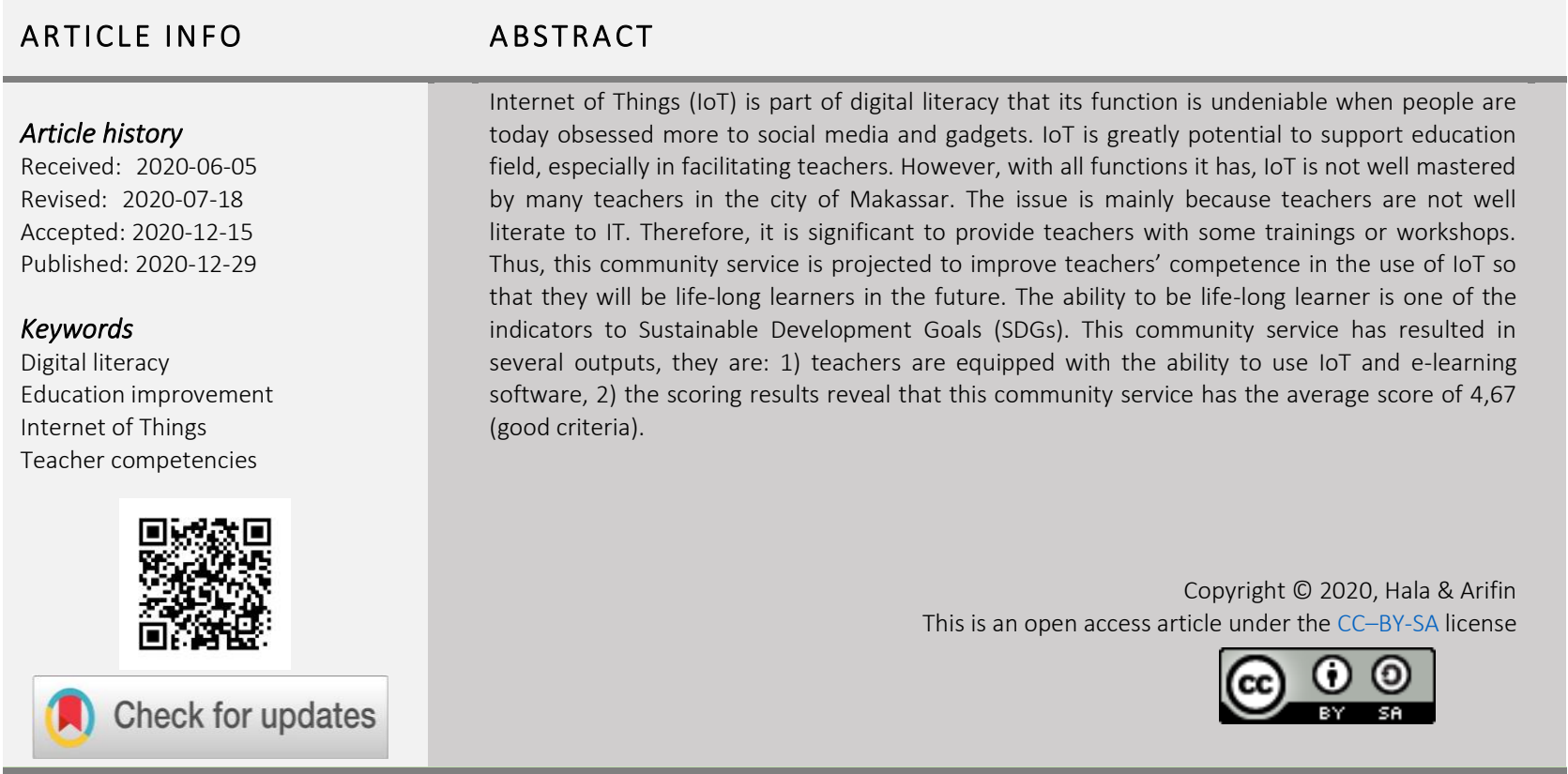

How to cite: Hala, Y., \& Arifin, A. N. (2020). Improving teachers' competence on the use of internet of things for teachers in the city of Makassar. Journal of Community Service and Empowerment, 1 (3), 156-161. doi: https://doi.org/10.22219/jpbi.v1i3.12420

\section{PENDAHULUAN}

Internet of Things (IoT) menjadi salah satu perkembangan teknologi yang telah menarik banyak perhatian di beberapa tahun terakhir (Whitmore et al., 2015; Yeo et al., 2014). Dalam konsep loT, seluruh "benda" yang berkaitan dengan kehidupan manusia akan terhubung dengan internet (Madakam et al., 2015). Melalui konsep ini, seluruh informasi dapat diakses dan dibagikan sehingga komunikasi dan pemonitoran segala sesuatu menjadi memungkinkan (Ng \& Wakenshaw, 2017; Want et al., 2015; Zhang, 2011). IoT pun akan menjadi paradigma komunikasi dominan dalam jaringan komunikasi dan akan menggantikan paradigma sebelumnya yang lebih condong pada komunikasi manusia ke manusia atau manusia ke mesin (Atzori et al., 2017).

Perkembangan teknologi loT akhirnya memberikan dampak posiif di berbagai aspek kehidupan (Abbas \& Yoon, 2015; Khan et al., 2012), termasuk aspek pendidikan (Abd-Ali et al., 2020; Aldowah et al., 2017). loT tidak hanya akan mengubah praktik pembelajaran konvensional, namun juga akan mengubah infrastruktur institusi pendidikan. Penerapan loT akan meningkatkan kualitas pendidikan di berbagai level sekolah hingga perguruan tinggi (Al-Emran et al., 2020; Kassab et al., 2020). Melalui penerapan loT, akses ke pendidikan juga akan menjadi lebih mudah.

Dalam pengaplikasiannya, sistem loT bermanfaat dalam penyelenggaraan e-learning (AjazMoharkan et al., 2017). IoT akan menyediakan kebutuhakan akses untuk penerapan pembelajaran secara elektronik. Dengan integrasi cloud computing dalam loT (Gubbi et al., 2013), guru akan dengan mudah mengakses berbagai bahan-bahan ajar. Cloud computing juga memudahlan guru untuk efisiensi penyimpanan data (Blue \& Tirotta, 2011; Pei et al., 2013) sehingga guru tak lagi memerlukan harddisk yang besar di dalam perangkat yang dimilikinya. Lebih lanjut, berbagai penelitian juga telah 
melaporkan penerapan pendidikan berbasis loT telah mampu meningkatkan hasil belajar siswa (Razzaque \& Hamdan, 2020; Syakroni et al., 2019).

Sayangnya, kesiapan guru di Indonesia untuk menerapkan loT diindikasikan masih rendah. Indikasi ini didasarkan pada penelitian yang melaporkan level literasi digital calon guru yang masih belum berkategori tinggi (Rizal et al., 2019). Keterampilan guru terhadap teknologi juga kurang optimal (Saddhono et al., 2019). Adapun penelitian yang menginfomrasikan banyaknya guru yang belum siap mengimplementasikan pembelajaran jarak jauh di masa pandemi (Atmojo \& Nugroho, 2020). Rendahnya kesiapan guru untuk mengimplementasikan loT juga nampak dari hasil observasi di Kota Makassar. Menanggapi kondisi tersebut maka peningkatan kompetensi guru perlu dilakukan agar para guru di Indonesia dapat memiliki kompetensi yang sesuai dengan perkembangan zaman.

Salah satu upaya peningkatan kompetensi guru adalah melalui Program Kemitraan Masyarakat (PKM) yang melibatkan dosen-dosen sebagai pelaksananya. Sejalan dengan pernyataan tersebut, beberapa publikasi telah melaporkan bahwa kegiatan pengabdian semacam ini dapat meningkatkan pemahaman dan keterampilan guru tentang teknologi informasi dan internet (Setiawan, 2018). Selain itu, pelatihan loT pada guru dan siswa di Purwakata juga dapat memperoleh respon postif yang didasarkan pada antusiasme dan partisipasi aktif para peserta pelatihan (Fuada et al., 2020). Begitu pula, pelatihan IOT pada guru SMA Tanwir Surabaya juga menunjukkan respon positif guru hingga mereka merasa bahwa kompetensi yang dikuasai akan diterapkan pada kelas masing-masing (Ningsih et al., 2021).

Berkaitan dengan kurang siapnya guru-guru di Kota Makassar dalam menerapkan loT, maka permasalahan ini disepakati untuk ditangani secara profesional oleh tim PKM. Program ini bertujuan untuk melatih guru dalam memanfaatkan sistem loT. Melalui pelatihan, guru juga diharapkan dapat mengembangkan sejumlah sumber belajar berbasis internet dan disesuaikan dengan kebutuhan pembelajaran di kelas masing-masing. Kegiatan PKM ini juga penting untuk dilakukan karena sejalan dengan salah satu dari 17 tujuan yang dirumuskan dalam Sustainable Development Goal (SDG). Tujuan yang dimaksud adalah tujuan keempat, yaitu "memastukan pendidikan yang inklusif dan berkuatias setara, juga mendukung kesempatan belajar seumur hidup bagi semua". Melalui peningkatan kompetensi guru dalam memanfaatkan IoT, maka realisasi loT dalam pendidikan Indonesia akan dapat terlaksana. Pengimplementasian IoT ini akan mendukung kondisi belajar seumur hidup bagi semua orang yang tertera di tujuan SDG tersebut.

\section{METODE}

Kegiatan PKM yang dilaporkan pada naskah ini berfokus pada peningkatan kompetensi pembelajaran berbasis loT bagi guru-guru di Kota Makassar. PKM ini dilaksanakan pada Bulan Juni 2019 di Celebes Global School (CGS), Makassar. Pelaksanaan kegiatan ini diikuti 12 orang guru dari multidisiplin ilmu. Persiapan-persiapan yang dilakaukan oleh tim PKM sebelum terjun ke lapang adalah: (1) melakukan studi pustaka tentang materi loT yang dibutuhkan oleh tenaga pendidik saat ini; (2) menyiapkan kebutuhan pelatihan tentang praktik loT; dan (3) menjadwalkan waktu pelaksanaan kegiatan pengabdian masyarakat.

Kegiatan PKM dilakukan dengan cara melaksanakan workshop dan demonstrasi langsung ke guru-guru. Kegiatan tersebut bertujua nmemberikan pemahamanan dan memberdayakan guru-guru agar dapat meningkatkan wawasan, pengetahuan, kemampuan, keterampilan dalam memanfaatkan loT. Materi yang disampaikan pada kegiatan PKM ini adalah: (a) konsep IoT, (b) pengenalan tools dalam loT, (c) praktik pengimplementasian loT dan multimedia pembelajaran, dan (d) pengenalan beberapa software yang mendukung pembelajaran e-learning.

Adapun metode yang digunakan adalah dengan: (1) melakukan presentasi dan diskusi langsung; (2) melakukan pelatihan dalam bentuk memberi tugas dan bimbingan kepada peserta dalam membuat soal menggunakan software Quiz creator dan pemanfaatan aplikasi berbasis google drive untuk menyimpan data-data penting siswa, guru dan sekolah; (3) melakukan diskusi dengan peserta untuk menyelesaikan persoalan terkait mengenai permasalahan yang dihadapi; serta (4) memberikan modul penggunaan Quiz creator.

\section{HASIL DAN PEMBAHASAN}

Pelaksanaan PKM yang dilakukan di CGS telah berhasil dilakukan dengan baik dan berjalan lancar. Kegiatan PKM ini telah melatih guru-guru di Kota Makassar untuk membuat bahan ajar serta meperkenalkan quiz creator kepada guru-guru tersebut. Kegiatan PKM diawali dengan pembukaan (Gambar 1), penjelasan terkait pentingnya loT dalam proses pembelajaran (Gambar 2), penjelasan terkait penggunaan quiz creator (Gambar 3 dan Gambar 4), hingga penutupan (Gambar 5).

Tabel 1. Hasil penilaian pelaksanaan kegiatan

\begin{tabular}{|c|c|c|c|}
\hline No & Uraian & Skor & Kriteria \\
\hline 1 & Materi yang disampaikan dalam PKM & 4,7 & Baik \\
\hline 2 & Respon masyarakat terhadap materi yang disampaikan & 4,7 & Baik \\
\hline 3 & Hubungan materi yang disajikan dengan kebutuhan masyarakat & 5,2 & Baik Sekali \\
\hline 4 & Keterkaitan antara materi dengan aplikasi yang dapat di serap di masyarakat & 4,7 & Baik \\
\hline 5 & Keterkaitan materi dengan kebutuhan & 4,7 & Baik \\
\hline 6 & Pemateri dan teknik penyajian & 4,5 & Baik \\
\hline 7 & Waktu yang digunakan dalam pemberian materi & 4,2 & Baik \\
\hline 8 & Kejelasan materi & 4,2 & Baik \\
\hline 9 & Minat masyarakat terhadap kegiatan & 4,8 & Baik \\
\hline 10 & Kepuasan kegiatan & 5 & Baik Sekali \\
\hline
\end{tabular}




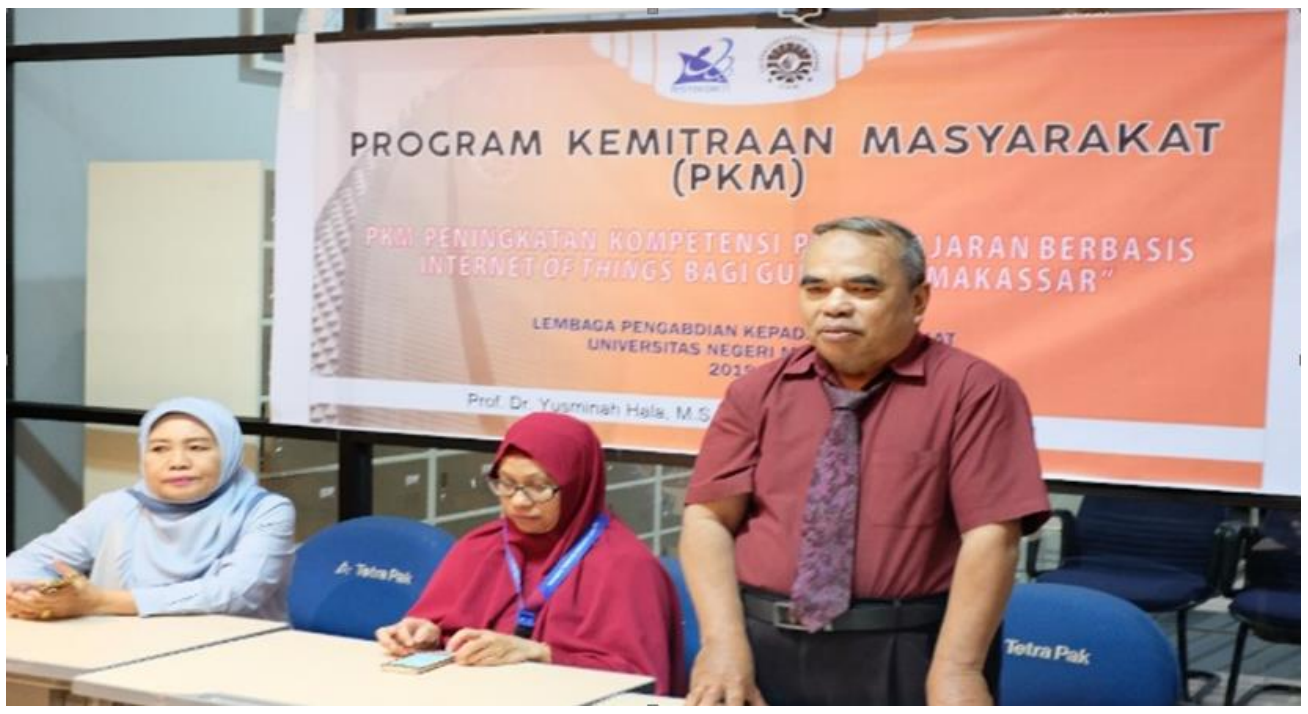

Gambar 1. Pelaksanaan pembukaan kegiatan PKM

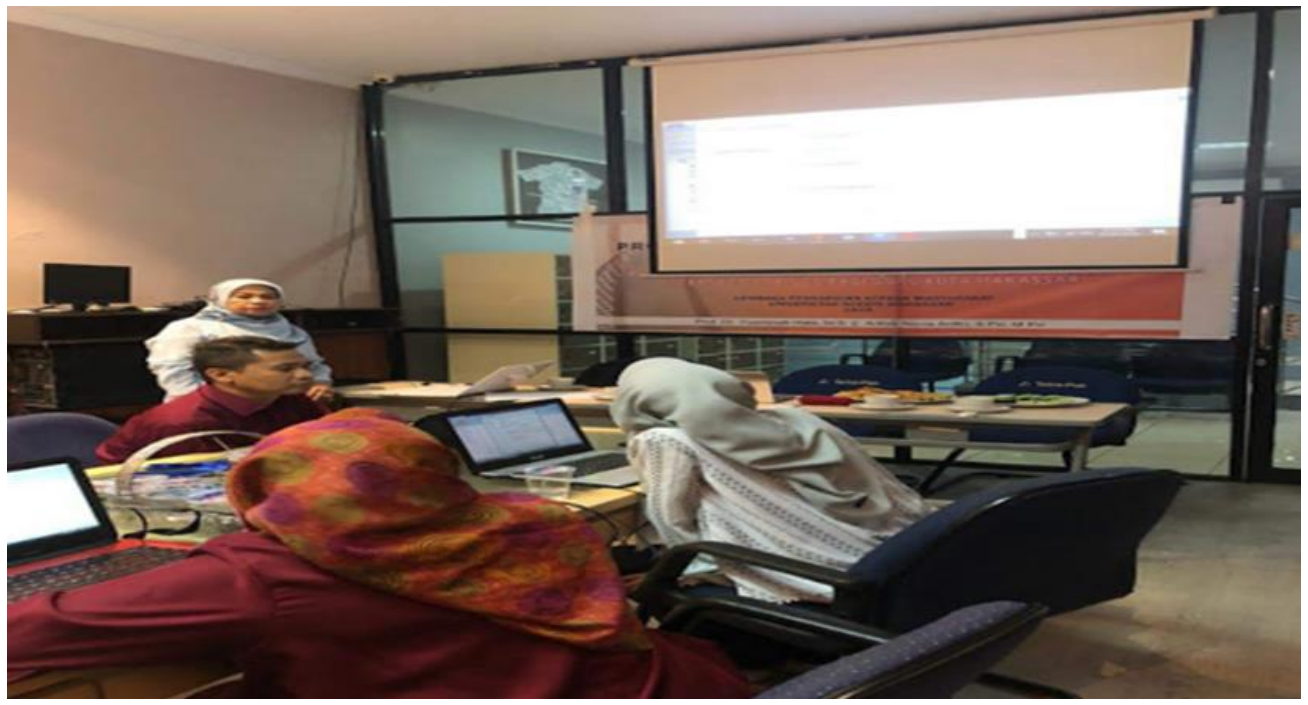

Gambar 2. Ketua tim menjelaskan mengenai pentingnya penggunaan aplikasi berbasis loT membantu proses pembelajaran

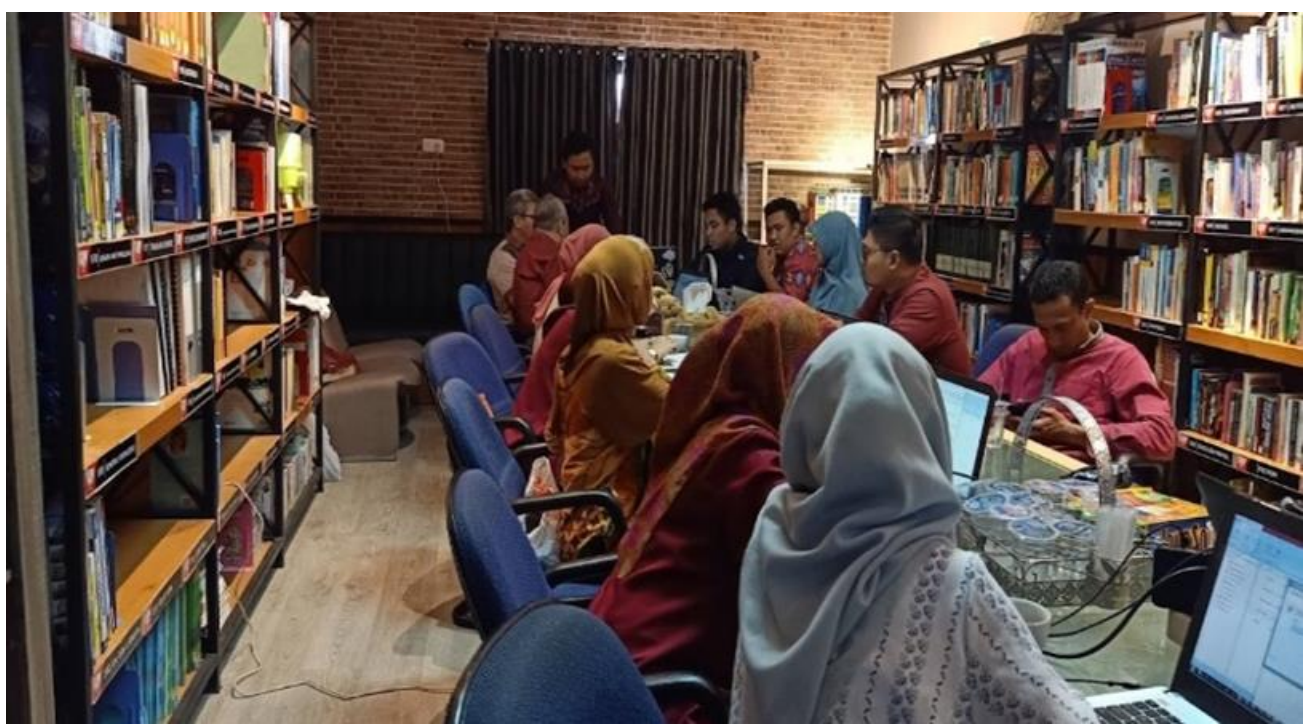

Gambar 3. Suasana peserta workshop PKM 


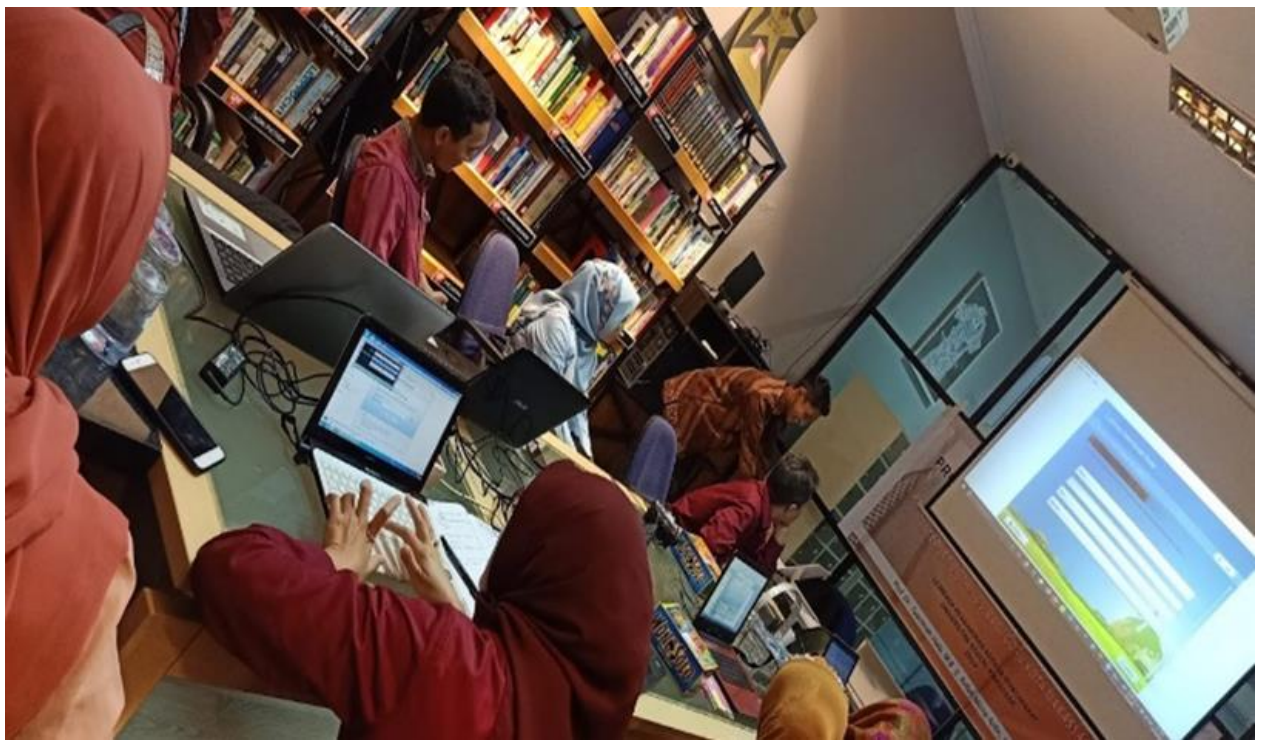

Gambar 4. Narasumber menjelaskan quiz creator kepada peserta workshop

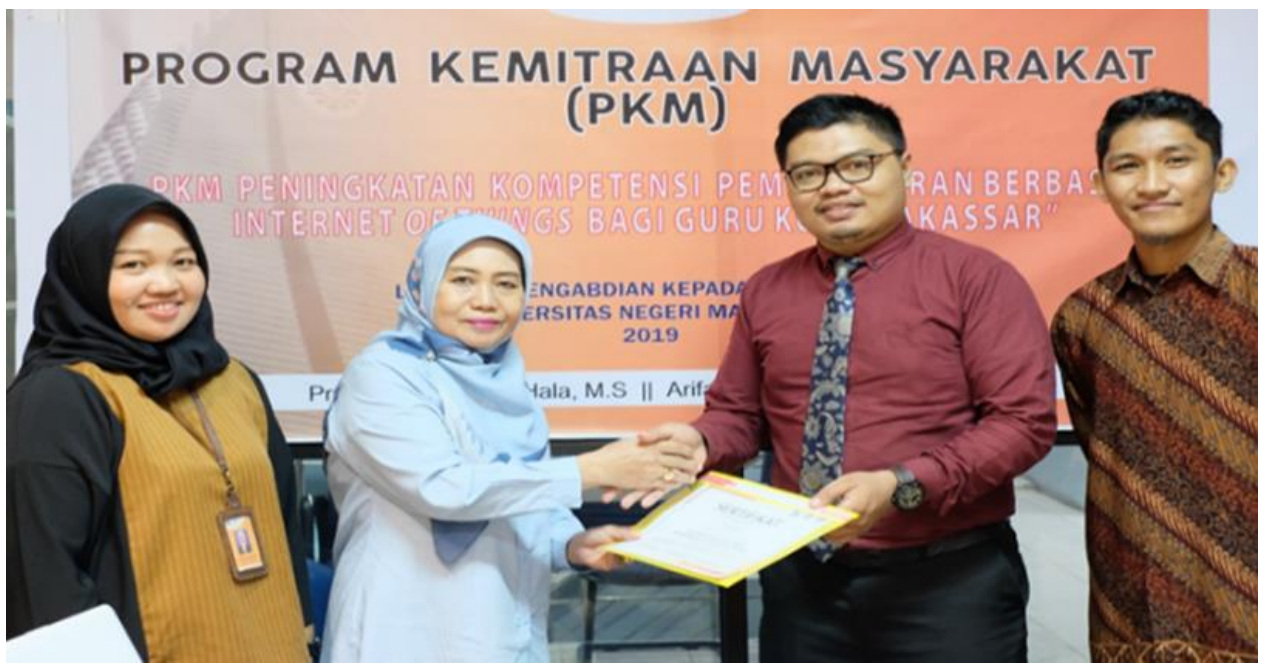

Gambar 5. Penyerahan bukti sertifikat pelatihan di akhir kegiatan workshop

Hasil observasi menunjukkan para guru antusias selama mengikuti kegiatan PKM. Antusiasme terlihat baik saat guru-guru menerima materi penjelasan maupun saat mencoba mempraktikkan pemanfaatan internet untuk pembelajaran di gawai masing-masing. Selain itu, pelatihan berupa pemaparan materi,tutorial, praktik langsung, serta diskusi juga berlangsung dengan lancar. Secara lebih detail, hasil analisis penilaian pelaksanaan kegiatan PKM oleh peserta disajikan melalui Tabel 1. Hasil penilaian kegiatan pelaksanaan PKM menunjukkan rerata skor 4,67 hal ini berarti kegiatan pelaksanaan berada pada kriteria baik.

Faktor pendukung kegiatan PKM adalah kebermanfaatan materi dalam mengelola pembelajaran. Pernyataan ini didukung oleh tanggapan seorang guru yang menyatakan bahwa pelatihan seperti ini sejalan dengan tuntutan program pemerintah saat ini. Selain itu, materi pelatihan sesuai dengan pembelajaran di era industri 4.0 yang menuntut siswa dan guru terus berpacu dengan waktu untuk memanfaatkan teknologi. Hal ini juga nampak dari kegiatan ujian tidak lagi sepenuhnya berbasis kertas. Selain itu, sekolah saat ini ditunjang dengan sarana dan prasarana IT dan guru didorong untuk memanfaatkan google drive sebagai tempat menyimpan data-data siswa, guru dan sekolah.

Bagaimanapun, selama pelaksanaan kegiataan PKM ini ada beberapa hal yang diidentifikasi sebagai faktor penghambat, diantaranya jaringan internet yang agak lambat dalam proses unduh dan unggah data. Rendahnya kemampuan dasar sebagian guru-guru memakai fasilitas internet juga menjadi faktor penghambat lain. Selama ini guruguru hanya berperan sebagai pengguna atau operator. Guru-guru yang ikut pelatihan mengaku bahwa faktor pengalaman dan kecakapan menggunakan software pembelajaran yang masih minim. Selain itu, pemanfaatan google drive belum maksimal digunakan oleh guru-guru.

Terlepas dari adanya beberapa hambatan yang ditemukan selama kegiatan PKM, program semacam ini diharapkan tetap dilaksanakan secara berkelanjutan. Pelatihan dan pendampingan para guru untuk mampu memahami hingga menguasai IoT merupakan kondisi yang diharapkan dapat mengoptimalkan pencapaian tujuan keempat dari SDG. 
Alasannya, melalui pengaplikasian IoT, guru dan pihak sekolah dapat menciptakan pembelajaran yang dapat diakses dimana saja, kapan saja, dan oleh siapa saja.

Penerapan IoT juga akan meningkatkan kualitas pendidikan secara menyeluruh (Al-Emran et al., 2020; Kassab et al., 2020). Sebagai contoh, IoT dapat mendukung terlaksananya e-learning dengan optimal (AjazMoharkan et al., 2017). Penggunaan e-learning yang optimal dapat memastikan terjaganya kualitas pendidikan di situasi kritis seperti di era pandemi COVID-19 saat ini. Selain itu, penerapan loT juga memungkinan para siswa mempelajari berbagai konsep dan teori secara menarik, mudah, dan mengikuti perkembangan ilmu terbaru. Siswa pun dapat berinteraksi dengan berbagao objek fisik secara virtual (Gómez et al., 2013). Tak heran, berbagai penelitian telah melaporkan manfaat penting penerapan loT terhadap motivasi hingga hasil belajar siswa performa belajar siswa (Razzaque \& Hamdan, 2020; Syakroni et al., 2019).

Perkembangan loT juga diprediksi dapat memberikan berbagai manfaat lain dalam dunia pendidikan. Manfaat pertama adalah guru akan dengan mudah menyimpan, mengakses, dan menyampaikan berbagai data yang berkaitan dengan pendidikan dan pembelajaran (Blue \& Tirotta, 2011; Gubbi et al., 2013; Pei et al., 2013). Manfaat kedua, pihak sekolah dapat memonitor aktivitas hingga kesehatan siswa (Zhong \& Li, 2020). Bahkan, performa siswa dapat dievaluasi dengan lebih sistematis melalui sistem loT (Verma \& Sood, 2018). Oleh karena itu, keterlibatan berbagai pihak untuk meningkatkan kompetensi guru dalam menguasai loT diharapkan dapat terlaksana secara berkelanjutan.

\section{KESIMPULAN}

Kegiatan PKM yang bertujuan meningkatkan pengetahuan dan keterampilan guru-guru di Kota Makassar terkait IoT telah dilakukan di CGS. Kegiatan ini telah berjalan dengan baik dan lancar. Beberapa faktor pendukung kegiatan PKM ini adalah dibutuhkannya materi ini oleh para guru dan ketersediaan fasilitas di lokasi pengabdian. Di sisi lain, faktor penghambat dari kegiatan PKM ini antara lain jaringan internet yang kurang cepat serta kurang terbiasanya guru menggunakan internet. Mengingat pentingnya pelatihan loT bagi para guru, maka kegiatan pengabdian semacam ini perlu dilakukan secara berkelanjutnya. Kegiatan semacam ini akan lebih mempersiapkan guru untuk mampu mendesan dan melaksanakan pembelajaran berbasis teknologi informasi yang sesuai dengan perkembangan zaman.

\section{UCAPAN TERIMA KASIH}

Ucapan Terima Kasih kepada Rektor Universitas Negeri Makassar (UNM) yang telah memberikan hibah Program Kemitraan Masyarakat PNBP PPs UNM. Selanjutnya ucapan terima terima kasih Ketua Lembaga Penelitian dan Pengabdian UNM, Direktur Program Pascasarjana UNM dan Guru-guru Celebes Global School (CGS) Kota Makassar yang telah memfasilitasi kegiatan ini.

\section{DAFTAR PUSTAKA}

Abbas, Z., \& Yoon, W. (2015). A survey on energy conserving mechanisms for the Internet of Things: Wireless networking aspects. Sensors, 15(10), 24818-24847. https://doi.org/10.3390/s151024818

Abd-Ali, R. S., Radhi, S. A., \& Rasool, Z. I. (2020). A survey: the role of the internet of things in the development of education. Indonesian Journal of Electrical Engineering and Computer Science, 19(1), 215. https://doi.org/10.11591/ijeecs.v19.i1.pp215-221

AjazMoharkan, Z., Choudhury, T., Gupta, S. C., \& Raj, G. (2017). Internet of Things and its applications in E-learning. 2017 3rd International Conference on Computational Intelligence \& Communication Technology (CICT), 1-5. https://doi.org/10.1109/CIACT.2017.7977333

Aldowah, H., UI Rehman, S., Ghazal, S., \& Naufal Umar, I. (2017). Internet of things in higher education: A study on future learning. Journal of Physics: Conference Series, 892, 012017. https://doi.org/10.1088/17426596/892/1/012017

Al-Emran, M., Malik, S. I., \& Al-Kabi, M. N. (2020). A Survey of Internet of Things (IoT) in education: Opportunities and challenges. In Studies in Computational Intelligence (pp. 197-209). Springer. https://doi.org/10.1007/978-3-03024513-9_12

Atmojo, A. E. P., \& Nugroho, A. (2020). EFL classes must go online! Teaching activities and challenges during COVID-19 pandemic in Indonesia. Register Journal, 13(1), 49-76. https://doi.org/10.18326/rgt.v13i1.49-76

Atzori, L., lera, A., \& Morabito, G. (2017). Understanding the Internet of Things: definition, potentials, and societal role of a fast evolving paradigm. Ad Hoc Networks, 56, 122-140. https://doi.org/10.1016/j.adhoc.2016.12.004

Blue, E., \& Tirotta, R. (2011). The benefits \& drawbacks of integrating cloud computing and interactive whiteboards in teacher preparation. TechTrends, 55(3), 31-39. https://doi.org/10.1007/s11528-011-0495-7

Fuada, S., Ichsan, I. N., Pratama, H. P., Putri, D. I. H., Suranegara, G. M., Setyowati, E., \& Fauzi, A. (2020). Workshop Internet-of-Things untuk guru dan siswa sekolah menengah di Purwakarta, Jawa Barat, guna menunjang kompetensi Era Industri 4.0. J-ABDIPAMAS (Jurnal Pengabdian Kepada Masyarakat), 4(2), 39.

https://doi.org/10.30734/j-abdipamas.v4i2.938 
Gómez, J., Huete, J. F., Hoyos, O., Perez, L., \& Grigori, D. (2013). Interaction system based on Internet of Things as support for education. Procedia Computer Science, 21, 132-139. https://doi.org/10.1016/j.procs.2013.09.019

Gubbi, J., Buyya, R., Marusic, S., \& Palaniswami, M. (2013). Internet of Things (IoT): A vision, architectural elements, and future directions. Future Generation Computer Systems, 29(7), 1645-1660. https://doi.org/10.1016/j.future.2013.01.010

Kassab, M., DeFranco, J., \& Laplante, P. (2020). A systematic literature review on Internet of things in education: Benefits and challenges. Journal of Computer Assisted Learning, 36(2), 115-127. https://doi.org/10.1111/jcal.12383

Khan, R., Khan, S. U., Zaheer, R., \& Khan, S. (2012). Future internet: The Internet of Things architecture, possible applications and key challenges. 2012 10th International Conference on Frontiers of Information Technology, 257260. https://doi.org/10.1109/FIT.2012.53

Madakam, S., Ramaswamy, R., \& Tripathi, S. (2015). Internet of Things (IoT): A literature review. Journal of Computer and Communications, 03(05), 164-173. https://doi.org/10.4236/jcc.2015.35021

Ng, I. C. L., \& Wakenshaw, S. Y. L. (2017). The Internet-of-Things: Review and research directions. International Journal of Research in Marketing, 34(1), 3-21. https://doi.org/10.1016/j.ijresmar.2016.11.003

Ningsih, N., Sutanto, T., \& Harianto, H. (2021). Pelatihan Internet of Things untuk guru SMA Tanwir Surabaya dengan menerapkan aturan social distancing pada SMA Tanwir. Jurnal Karya Abdi Masyarakat, 4(3), 687-695. https://doi.org/10.22437/jkam.v4i3.11659

Pei, X. L., Wang, X., Wang, Y. F., \& Li, M. K. (2013). Internet of Things based education: Definition, benefits, and challenges. Applied Mechanics and Materials, 411-414, 2947-2951. https://doi.org/10.4028/www.scientific.net/AMM.411-414.2947

Razzaque, A., \& Hamdan, A. (2020). Internet of Things for learning styles and learning outcomes improve e-learning: A review of literature. Proceedings of the International Conference on Artificial Intelligence and Computer Vision (AICV2020), 783-791. https://doi.org/10.1007/978-3-030-44289-7_73

Rizal, R., Setiawan, W., \& Rusdiana, D. (2019). Digital literacy of preservice science teacher. Journal of Physics: Conference Series, 1157, 022058. https://doi.org/10.1088/1742-6596/1157/2/022058

Saddhono, K., Mulyaningsih, I., Sudarsana, I. K., \& Manurung, R. T. (2019). Indonesian language teachers' attitudes toward ICT utilization in learning for elementary school in Surakarta. Journal of Physics: Conference Series, 1254, 012062. https://doi.org/10.1088/1742-6596/1254/1/012062

Setiawan, H. S. (2018). Pelatihan guru dalam penggunaan Internet of Things pada Madrasah Darussa'adah. E-Dimas: Jurnal Pengabdian Kepada Masyarakat, 9(2), 167-176. https://doi.org/10.26877/e-dimas.v9i2.1554

Syakroni, A., Zamroni, Muali, C., Baharun, H., Sunarto, M. Z., Musthofa, B., \& Wijaya, M. (2019). Motivation and learning outcomes through the Internet of Things; Learning in pesantren. Journal of Physics: Conference Series, 1363, 012084. https://doi.org/10.1088/1742-6596/1363/1/012084

Verma, P., \& Sood, S. K. (2018). Internet of Things-based student performance evaluation framework. Behaviour \& Information Technology, 37(2), 102-119. https://doi.org/10.1080/0144929X.2017.1407824

Want, R., Schilit, B. N., \& Jenson, S. (2015). Enabling the Internet of Things. Computer, 48(1), 28-35. https://doi.org/10.1109/MC.2015.12

Whitmore, A., Agarwal, A., \& Da Xu, L. (2015). The Internet of Things -A survey of topics and trends. Information Systems Frontiers, 17(2), 261-274. https://doi.org/10.1007/s10796-014-9489-2

Yeo, K. S., Chian, M. C., Wee Ng, T. C., \& Tuan, D. A. (2014). Internet of Things: Trends, challenges and applications. 2014 International Symposium on Integrated Circuits (ISIC), 568-571. https://doi.org/10.1109/ISICIR.2014.7029523

Zhang, Y. (2011). Technology framework of the Internet of Things and its application. 2011 International Conference on Electrical and Control Engineering, 4109-4112. https://doi.org/10.1109/ICECENG.2011.6057290

Zhong, C.-L., \& Li, Y. (2020). Internet of things sensors assisted physical activity recognition and health monitoring of college students. Measurement, 159, 107774. https://doi.org/10.1016/j.measurement.2020.107774 